\title{
NEW LEAF SPECIES FROM THE UPPER MIOCENE FLORA OF THE LEAF-BEARING WISCHGRUND CLAY (LOWER LUSATIA, BRANDENBURG, GERMANY)
}

Dedicated to Prof. Zlatko Kvaček in appreciation.

URSULA STRIEGLER

Rostocker Str. 40, D-03046 Cottbus, Germany; e-mail: u.r.striegler@web.de.

Striegler, U. (2021): New leaf species from the upper Miocene flora of the leaf-bearing Wischgrund clay (Lower Lusatia, Brandenburg, Germany). - Fossil Imprint, 77(1): 102-110, Praha. ISSN 2533-4050 (print), ISSN 2533-4069 (online).

\begin{abstract}
This is a brief outline of the fossil content of the Wischgrund leaf-bearing clay (Lower Lusatia, Brandenburg State, Germany), which belongs to the youngest Neogene layers of Lower Lusatia (upper Miocene, Tortonian). It is a deciduous temperate flora, with a small proportion of evergreen species. The reconstructed vegetation can be assigned to an azonal swamp forest with Taxodium and a riparian forest with Liquidambar and Acer as the most frequent species. Furthermore, a zonal Mixed Mesophytic Forest characterized by Quercus and Fagus is proposed in upland positions. The flora consists of 78 species of leaves, 51 carpological species and 82 palynological groups. The climate belongs to Cfa-type according to Köppen. Two new species of leaves are described from there, Pyracantha pseudococcinea sp. nov. and Ternstroemites klettwitzensis sp. nov.
\end{abstract}

Key words: new species of leaves, leaf-bearing clay of Wischgrund, Lower Lusatia, upper Miocene, Pyracantha, Ternstroemites

Received: May 5, 2021 | Accepted: July 31, 2021 | Issued: December 9, 2021

\section{Introduction}

The Lower Lusatia is situated in the North-western European Tertiary depression. The Neogene period is characterized here by alternation between shallow marine to brackish deposits from the Paleo-North Sea and fluvial deposits from the southern mainland, and the repeated extended formation of brown coal seams. Carpological investigations have shown climatic variations, which are expressed in the macroflora zones set up by Mai (1967), later in floral complexes (Mai 1995). The youngest Neogene strata have been opened up on a large extent since the middle of the $19^{\text {th }}$ century by mining of the $1^{\text {st }}$ and $2^{\text {nd }}$ Lausitz seams, which made extensive research into the Tertiary flora possible.

The Rauno Formation with the $1^{\text {st }}$ Lausitz seam as a striking horizon and the Wischgrund leaf-bearing clay a few meters above it are almost exclusively preserved in erosion remnants of the Pleistocene ice sheet, so-called Tertiary plateaus.

This sequence of layers is particularly rich in fossil plant accumulations (Menzel 1906, Menzel et al. 1933, Striegler and Striegler 1984, Striegler 1990, Striegler et al. 2004).

Among the youngest sediments on the Klettwitz plateau, there is the Wischgrund leaf-bearing clay, and other leafbearing clay lenses in the same stratigraphic position

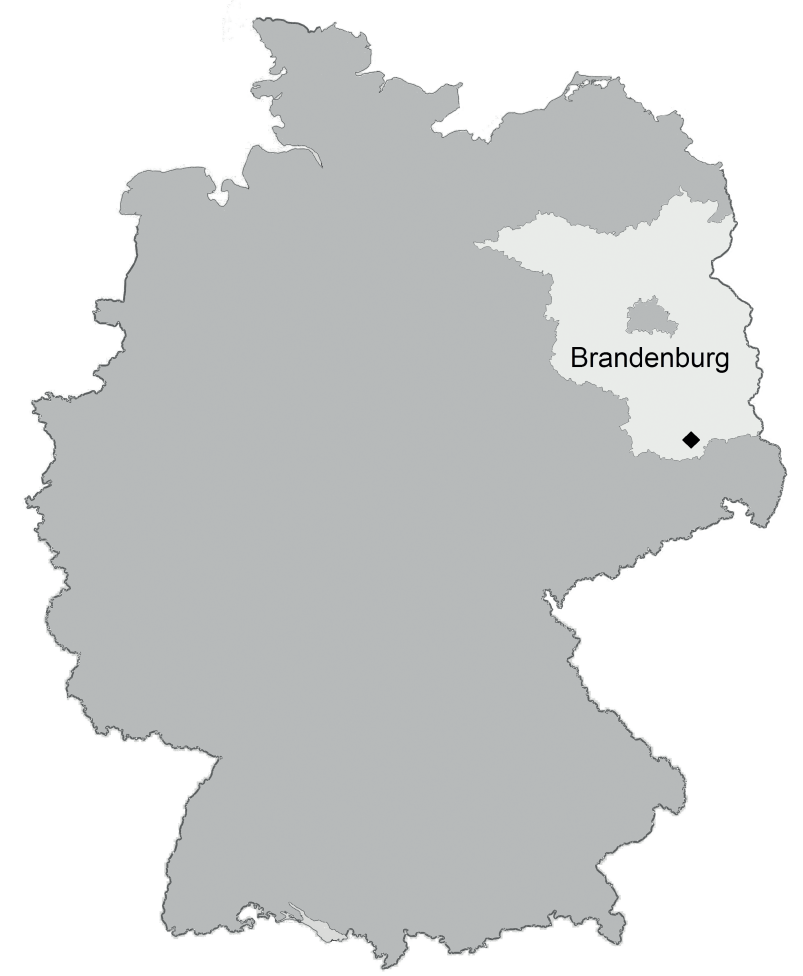

Text-fig. 1. Position of the outcrops of the Wischgrund leaf-bearing clay. 


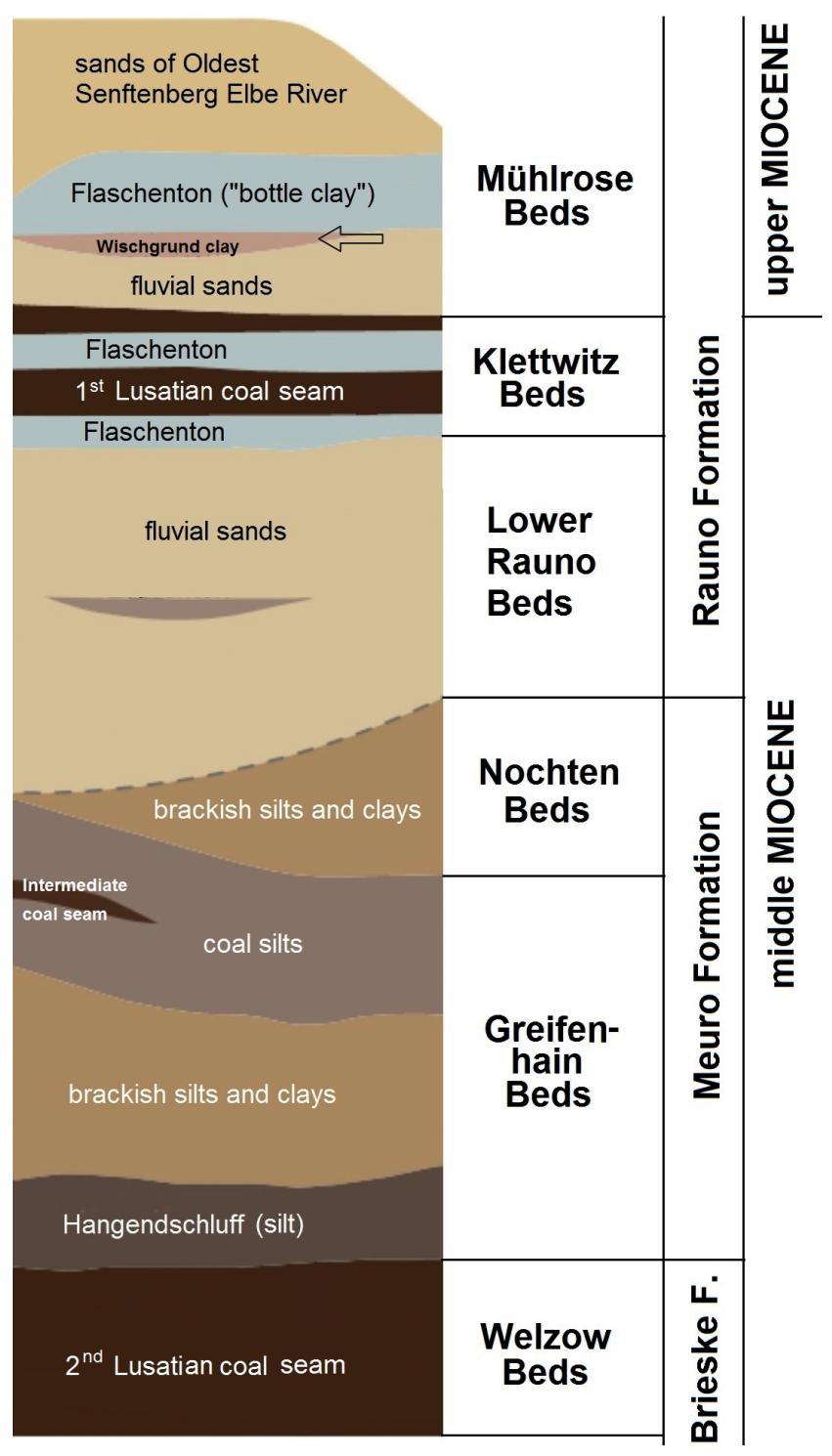

Text-fig. 2. Stratigraphic position of the Wischgrund leaf-bearing clay (arrow) on the Klettwitz Tertiary plateau.

(Bergheide 1 and 2, opencast mine Klettwitz), from which finds are presented here. They are interpreted as oxbow lake sediments within the fluvial deposits of the fossil Elbe River above the $1^{\text {st }}$ Lusatian seam horizon (Text-figs 1,2 ).

These leaf-bearing layers belong to the floristic complex "Schipkau" (floristic zone XIII) according to Mai (1995), which is stratigraphically classified in the Mühlrose Beds of the Rauno Formation, lower upper Miocene (Tortonian) (Menning and Deutsche Stratigraphische Kommission 2012, Menning 2015, Standke et al. 2010, Standke 2015). Pollen analysis of the Wischgrund leaf-bearing clay also indicates upper Miocene age (Médus and Striegler 2002).

Publications on the palaeobotanical investigations of fossil leaves from these horizons, which are housed in the Cottbus Museum, are from Striegler and Striegler (1981), Striegler (1985, 1990, 1992), Fischer and Striegler (1992), and Ablaev and Striegler (1992). According to Mai (1989, 2000, 2001a, b), there were extensive studies on carpological findings. Palynological examinations were carried out by J. Médus, Marseille (Médus and Striegler 2002). In summary, leaves of the deposits were studied by Striegler (2017).

\section{Material and methods of evaluation}

Since the fossil deposits from the most recent Neogene layers of Lower Lusatia have largely disappeared due to clay and lignite mining, it is all the more important that in the Städtischen Sammlungen Cottbus, Department of Geology, there is an extensive palaeobotanical collection from the Wischgrund leaf-bearing clay (about 11,000 specimens). It was collected between 1974 and 1986, shortly before dredging the Klettwitz opencast mine.

The specified Inv. Nos refer to material in the Städtische Sammlungen Cottbus, Department of Geology.

The investigated material is mostly preserved as leaf impressions without cuticle (predominantly limonitized), so the determination was mainly carried out by morphological evaluation, which also applies to the new species presented here. Pyracantha pseudococcinea sp. nov. (Rosaceae) is represented by 4 specimens and Ternstroemites klettwitzensis sp. nov. (Theaceae s. 1.) by 57 specimens.

The new names are registered with a unique PFN numbers in the Plant Fossil Names Registry, hosted and operated by the National Museum, Prague for the International Organisation of Palaeobotany (IOP).

\section{Overview of the fossil content of the leaf- bearing clay of Wischgrund}

Summary investigation results of the leaves from the Wischgrund leaf-bearing clay, as well as the joint evaluation of leaf, carpological (Mai 1989, 2000, 2001a, b) and palynological (Médus in Médus and Striegler 2002) investigations were published by Striegler (2017) and will serve as a basis for the overview here.

Seventy-eight taxonomic species of leaves (incl. 77 woody plants), fifty-one carpological species (incl. 28 woody plants) and eighty-two palynological groups (incl. 47 woody plants) were determined from these leaf-bearing clays. They can be largely attributed to deciduous temperate forest (only $16 \%$ to $17 \%$ of the leaves, $22 \%$ of the fruits/seeds and $11 \%$ of spores/pollen belong to evergreen species).

The results of the previous study show that the leafbearing clay contained plant fossils interpreted as being part of swamp and riparian forest vegetation.

The swamp forest is characterized by Taxodium dubium (Sternb.) Heer (emended by Kunzmann et al. 2009). Other components are Nyssa cf. haidingeri (ETTINGSH.) KVAČEK et BŮŽEK / N. ornithobroma Unger, Betula cf. subpubescens GöPP. (emended by Worobiec 2007) and Myrica lignitum (UnGer) SAPORTA.

The most important components of the riparian forest are Liquidambar europaea A.BRAUN in Buckland (1836) and $L$. triloba GOTHAN et SAPPER, complemented in decreasing order by Acer tricuspidatum Bronn, Sequoia abietina (BRONGn.) ERw.Knobloch, Populus balsamoides Göpr. / Populus latior A.Braun, Parrotia pristina (EtTingsh.) Stur, Sassafras ferretianum A.MASSAL. et ScARAB., Alnus julianiformis (Sternb.) KvaČex et Holý, Pyrus wischneideri Striegler, Ulmus fischeri HeER and U. pyramidalis GöPP., Populus populina (Brongn.) Erw.KnOBloch, Alnus cf. adscendens (Göpr.) Zastawn. et H.Walther, Cercidiphyllum crenatum 
(Unger) R.W.Br., Salix cf. longa A.Braun, Zelkova zelkovifolia (UNGER) BŮŽEK et KOTLABA and others.

Representatives of zonal vegetation include taxa from mixed mesophytic forests (MMF), according to the Integrated plant record (IPR) vegetation analysis (KovarEder and Hably 2006, Kovar-Eder and Kvaček 2007, Kovar-Eder et al. 2008). In this case it is Fagaceae forest, comprising drier areas with predominantly Quercus, represented by various species of subgenus Cerris $\mathrm{SPACH}$, as well as Quercus pseudocastanea Göpr., and wetter areas with predominantly Fagus, represented by Fagus menzelii KvačEK et H.WALther and Fagus cf. silesiaca var. gozdnicensis ZASTAWN. et KVAČEK.

Other fossil plant representatives, in decreasing order of leaf findings, are Pinus cf. hepios (Unger) HeER / Pinus hampeana (Unger) HeER, Distylium fergusonii ERw.KNOBLOCH et KvačEK, Quercus (Cyclobalanopsis) wischgrundensis $\mathrm{S}$ TRIEGLER, Ternstroemites klettwitzensis sp. nov., Cephalotaxus ex gr. harringtonia (KNIGHT ex J.ForBes) K.Koch fossilis MAI et H.WALTHER, Ulmus ruszovensis A.Hummel, Berberis sp., Castanea cf. sativa Mıl., Carya serrifolia (GöPp.) KRÄUSEL, Carpinus grandis Unger, Paliurus tiliifolius (Unger) BŮžEK / Paliurus favonii Unger, cf. Quercus rhenana (KräUSEL et WeYland) ERw.KNOBLOCH et Kvačex, Pyracantha pseudococcinea sp. nov., Betula cf. plioplatyptera A.Hummel, Magnolia kristinae ERw.KNOBLOCH et KVAČEK, aff. Smilax sp., Laria cf. rueminiana (HEER)
G.Worobiec et KVAČEK and other species. In addition, the following species are represented by carpological remains: Magnolia ludwigii EtTINGsh., Sphenotheca incurva KIRCHн., Symplocos lignitarum (Quenst.) KIRCHн. and Eomastixia saxonica (MENZEL) HolÝ.

Recent comparable species are found in deciduous forests and less often in laurel forests of southeastern North America, Europe as far as Transcaucasia-Northern Iran and the Sino-Japanese region.

The climate belongs to the Cfa type according to Köppen, as Mai (2001a) indicated for the floristic complex "Schipkau".

The flora of the Wischgrund leaf-bearing clay is the basis for the "Lower Lusatian Tertiary Forest", a botanical garden of the earth's history (Text-fig. 3). In the Cottbus Spreeauenpark there is a 1.7 ha area laid out as a museum complex, in which landscape and plant life on the banks of the fossil Elbe are recreated by comparable recent species, intended as a reconstruction of this specific site of Wischgrund. The woods are assigned to swamp forest, Fagacean forest, peatbog bushes and riparian forest (Striegler and Striegler 2002). The complex is complemented by a reconstruction of the Niederlausitzer Kohlemoor (Schneider 2002).

With the summary studies of the Wischgrund flora (Striegler 2017) and the present supplement, the treatment of the fossil macroflora of Lower Lusatia, which Menzel started in 1906, was continued. Due to the closure of

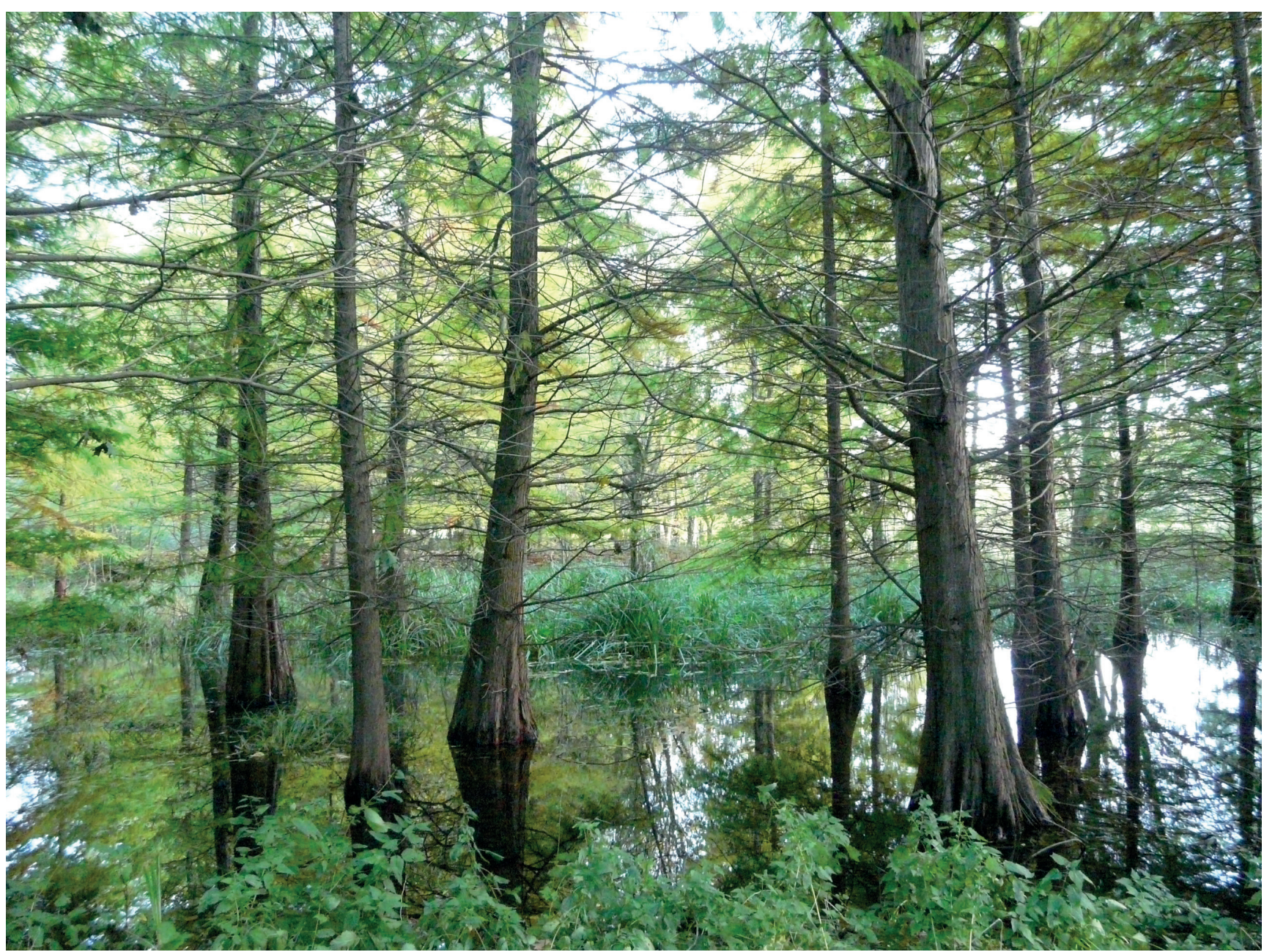

Text-fig. 3. Lower Lusatian Tertiary Forest in Cottbus: Taxodium swamp. 
lignite mining in the near future, not many new finds are to be expected. But thanks to the systematic collection and documentation activities (Striegler and Striegler 1981, Striegler et al. 2004), there is rich palaeobotanical material in the Cottbus collections, including sediment samples, which makes further research possible.

\section{Systematic palaeobotany}

\section{Family Rosaceae Juss., 1789 nom. cons.}

\section{Genus Pyracantha M.Roem., 1847}

\section{Pyracantha pseudococcinea sp. nov.} Text-fig. 4

2017 aff. Pyracantha Roemer sp.; Striegler, pp. 26, 27, pl. 29, fig. 1 (Wischgrund).

H o l o ty pe. Inv.-No. 3470-3 (Striegler 2017: pl. 29, fig. 1; Text-fig. 4a herein).

Repository. Städtische Sammlungen Cottbus, Departement of Geology, Cottbus, Germany.

Plant Fossil Names Registry Number. PFN002688.

Ety mology. Similar to leaf margin and venation comparable with $P$. coccinea, but outline ovate to elliptical instead of obovate as typical for $P$. coccinea.

Diagnosis. Small leaves with a petiole, lamina narrowly ovate to elliptical, base obtuse to rounded, apex incomplete, obtuse to probably acute with indistinct mucro. Leaf margin irregularly flat crenate. Primary vein strong, secondaries semicraspedodromous, bifurcated in different places, forming narrow arches with each other and with intersecondary veins; tertiary veins usually branching obliquely from the secondary veins and are perpendicular to the primary vein; fine veinlets entering into the tooth sinus from the outer vein arches.

Type locality. Clay pit Wischgrund near Lauchhammer, Lower Lusatia, Brandenburg, Germany (devastated by Klettwitz opencast mine in the year 1987).
Type horizon. Upper Miocene, Tortonian, Rauno Formation, Mühlrose Beds, floristic complex "Schipkau" (macrofloristic zone XIII according to Mai 1995), leafbearing clay of Wischgrund.

Occurrence in Lower Lusatia. Upper Miocene, floristic complex "Schipkau", clay pit Wischgrund.

Materia 1. Wischgrund: 4 leaves: 3470-3, 11034, 18279-1, 18372-1.

Description. Apex mostly not completely preserved; length approx. 16 to $33 \mathrm{~mm}$, width 8.5 to $15 \mathrm{~mm}$, ratio length/width approx. 1.9 to 2.45 .

Teeth: 0.2 to $0.4 \mathrm{~mm}$ high, 1.1 to $1.4 \mathrm{~mm}$ wide, widening towards the base of the leaf (up to $3 \mathrm{~mm}$ ) to entire margins, partly with glands.

Venation: primary vein almost straight, approx. 10 secondary veins on each side at an angle of $30^{\circ}$ to $55^{\circ}$ and at a distance of (1.5) 2.2 to $3.5 \mathrm{~mm}$ from the primary vein, tertiary veins forking and usually forming elongated areas; higher order veins reticulate (areoles size approx. $0.5 \mathrm{~mm}$ ).

R e m a r k s . Typical of Pyracantha, leaves have a strong primary vein, irregular bifurcation of the secondaries, mostly perpendicular course of the tertiary veins to the primary vein, crenate margin and course of the veinlets mostly in the sinus of the teeth.

Since the venation and the formation of the margin agree very well with Pyracantha, especially with Pyracantha coccinea M.RoEm., these leaves should be classified here as the new species Pyracantha pseudococcinea. There is no direct comparison with recent species. The leaf outlines of Pyracantha are rather obovate, or with obtuse to rounded apex and acute base. However, ovate leaf outlines with an obtuse to rounded base like the leaves of Wischgrund can also occur in some recent species. Crenate leaf margin is typical for most recent Pyracantha species. Apex with mucro is known from coccinea and crenulata (from Krüssmann 1978 and herbarium Striegler; Text-fig. 5).

Fossil Pyracantha leaves are known from the Oligocene to the Pliocene. The fossil species Pyracantha kraeuselii H.WALther in Mai and Walther (1978) is known from the Oligocene of the Haselbacher series (White Elster Basin;
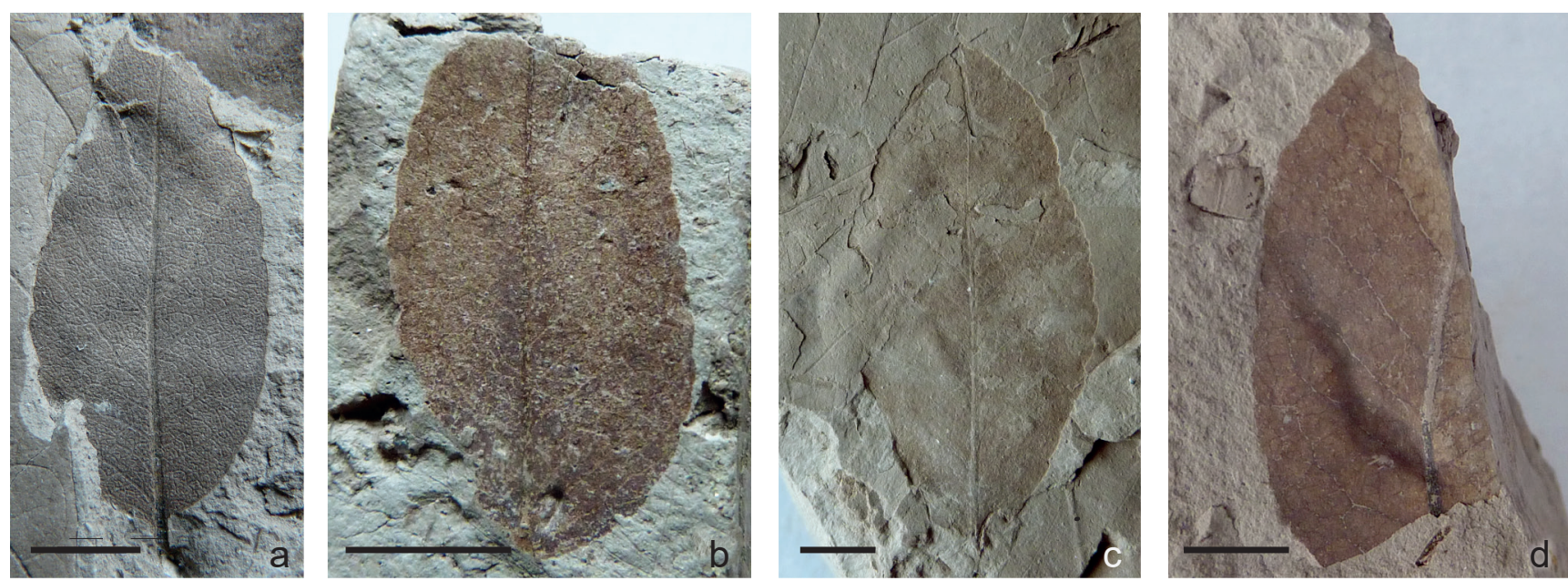

Text-fig. 4. Pyracantha pseudococcinea sp. nov. a: Holotype, Inv.-No. 3470-3, scale bar 5 mm; b: Inv.-No. 11034, scale bar 5 mm; c: Inv.-No. 18279, scale bar 5 mm; d: Inv.-No. 18372, scale bar 5 mm. 


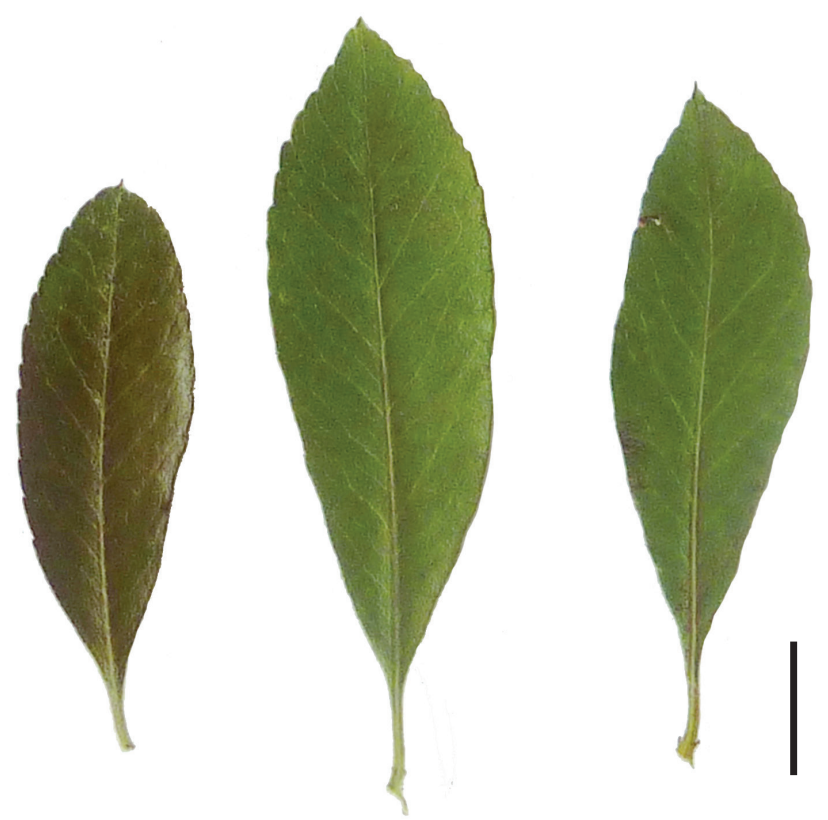

Text-fig. 5. Pyracantha coccinea M.RoEM. (Cottbus, herbarium Striegler). Scale bar $10 \mathrm{~mm}$.

Walther 1980) as well as the late Oligocene of Enspel in the Westerwald region (Köhler and Uhl 2014), and from Bechlejovice in České Středohoři Mountains (Kvaček and Walther 2004). The leaves of Wischgrund cannot be compared with this species, because Pyracantha kraeuselii was erected with features of the epidermis, and differs in morphology from the leaves presented here, having acute base and obtuse apex. There is also no morphological correspondence with other fossil species. Fossil species are often compared with Pyracantha coccinea, which usually have obovate shape, such as Pyracantha cf. coccinea (Givulescu 1984, 1990) from the upper Miocene of Chiuzbaia, Romania. Pyracantha coccinea described by Zastawniak (1980) from the Sarmatian of the Holy Cross Mts., Poland, is very narrow elliptic. P. nipponica TANAI (Tanai 1976) from the Pliocene of Mogi, Japan, is widely elliptic.

Mai (2001a) describes carpological finds as Pyracantha acuticarpa (C.REID et E.REID) SzAFER for the floristic complex "Schipkau" from various sites in Lower Lusatia (Klettwitz, Welzow, Bröthen).

\section{Family Theaceae s. I. Mirb. ex Ker Gawl., 1816 nom. cons.}

\section{Genus Ternstroemites E.W.BERRY, 1916}

\section{Ternstroemites klettwitzensis sp. nov.}

$$
\text { Text-figs 6, } 7
$$

2017 Dicotylophyllum sp. 6; Striegler, pp. 73, 74, pl. 34, figs 4 to 6 (Wischgrund).

H o l o t y p e. Inv.-No. 19076-2 (Striegler 2017: pl. 34, fig. 6; Text-fig. 6a, b herein).

Repository. Städtische Sammlungen Cottbus, Departement of Geology, Cottbus, Germany.

Plant Fossil Names Registry Number. PFN002689.
Etymology. According to the Klettwitz opencast mine, type locality of the species.

D i a g n o s i s . Lamina narrow elliptical, base acute, apex attenuate; ratio length/width 3.5 to 5.9; margin uniserrate, teeth crenulate pressed to acute with glands, in the lower area only glands. Primary vein strong, secondary veins thin, irregular brochidodromous, meandered or kinked, partly forked from the innermost third, connected by irregular arches, from marginal arches short veins running into the teeth. Tertiary veins irregular reticulate. Petiole short and thick.

Type locality. Clay pit Wischgrund near Lauchhammer, Lower Lusatia, Brandenburg, Germany (devastated by Klettwitz opencast mine in the year 1987).

Type horizon. Upper Miocene, Tortonian, Rauno Formation, Mühlrose Beds, floristic complex "Schipkau" (macrofloristic zone XIII according to Mai 1995), leafbearing clay of Wischgrund.

Occurrence in Lower Lusatia. Upper Miocene floristic complex "Schipkau": clay pits Wischgrund and Bergheide (outcrop 2).

M a t e ri a 1. Wischgrund: 56 leaves, Inv.-No. 3047-4, 3358-1, 3367-1, 3474-3, 7218-4, 11020-5, 11024-1, 11025-1, $11026,11033-4,11100-7,11322-14+15,17802-2,17833-1$, 17847-1, 17851-2, 17872-5, 17894-2 18001, 18014, 18023-1, 18025-1, 18031-1, 18042-1+2, 18044-1, 18047-1, 18049-1, $18050-1,18051-1,18053-1,18056,18058,18060-1$, $18061-1,18063-1,18064-1,18070-1,18073,18079-1$, $18080-1,18091-1,18092-1,18093,18095-1,18102-1$, 18103-1, 18105-2, 18360-1, 19076-2, 19462-16, 19835-8, 19862-1, 22721-4, 22729-1. Bergheide 2: 1 leaf, Inv.-No. $14901 / 370-5$.

D e s c r i p t i o n . Lamina narrow elliptical, some leaves slightly curved, sides mostly convex, base acute, running down at the petiole, apex attenuate; length approx. 40 to $80 \mathrm{~mm}$, width 8 to $18 \mathrm{~mm}$; petiole 2 to $5 \mathrm{~mm}$ long and $1 \mathrm{~mm}$ wide.

Margin with 6 to 13 simple small teeth or glands per $\mathrm{cm}$, directly at the base without teeth; above that, usually only glands; further up teeth, partly crenulate pressed with upward pointing glands or acute and obliquely diverging upwards with or without glands, teeth up to $0.2 \mathrm{~mm}$ protruding beyond the margin of the leaf.

Venation pinnate; primary vein strong (to $1.25 \mathrm{~mm}$ ), straight or curved with the leaf; about 12 secondary veins on each side, brochidodromous, very rarely eucamptodromous, irregular, meandering to kinked, partly forked (partly already in the innermost third), leaving the primary vein with an angle of $40^{\circ}$ to $70^{\circ}$ at a distance of 1.5 to $6 \mathrm{~mm}$, and connected with the next secondary vein 1 to $3 \mathrm{~mm}$ away from the margin by clear, usually wide irregular arches. At the base of the leaf, steep veins $\left(25^{\circ}\right.$ to $\left.35^{\circ}\right)$ go off from the primary vein on each side. They lead up parallel to the margin and disappear in the fine vein network. The arches of the secondary veins are joined by irregular marginal arches, from which short veins go into the teeth. Tertiary veins predominantly irregular reticulate, also connected with intersecondary veins, in the direction of the margin of the leaf also loose percurrent. 
R e marks. Similar narrow leaves occur in different families.

The assignment to Theaceae s. 1. is most likely, because Theaceae s. 1. are characterized by brochidodromous venation. Glandular formation along the margin of the Wischgrund leaves have a counterpart in strong leathery extant evergreen leaves of Theaceae s. 1., while the deciduous species are characterized by fine serrate to ciliate margin (see Kvaček and Walther 1984a, b). The strong primary vein, thin secondary veins and short broad petiole are another similarity to Theaceae s. 1 .

The venation of the Wischgrund species is similar to that of Berberis leaves, but while Berberis leaves have acute thorny teeth, these leaves have glandular teeth, and they are also different from Berberis sp. of Wischgrund due to closer distance of the secondary veins and teeth.

Styrax leaves differ from Wischgrund leaves by parallel tertiary veins (Schweigert 1992).
Salix leaves can also be similar, but mostly they have eucamptodromous venation and the arches of the secondary veins are closer to the margin, the tertiary veins are clearly percurrent.

The leaves cannot be assigned to any described fossil Theaceae s. 1. species. In a large part of the fossil (Eocene to Pliocene) Theaceae s. str. leaves, e.g., Gordonia, Schima, Polyspora and the genus ?Cleyera of the Pentaphylacaceae family, the diagnosis is based on both large morphology and leaf epidermal anatomy (e.g., Kvaček and Walther 1984a, b, Kovar-Eder and Meller 2001, Kovar-Eder and Hably 2006), which cannot be examined on the Wischgrund leaves. In addition, their venation is partially poorly preserved. Thus, the typical large-morphological features of Wischgrund cannot be compared with them. ?Gordonia sp. of Kovar-Eder and Meller (2003) might be similar, but is too incomplete for closer comparison.
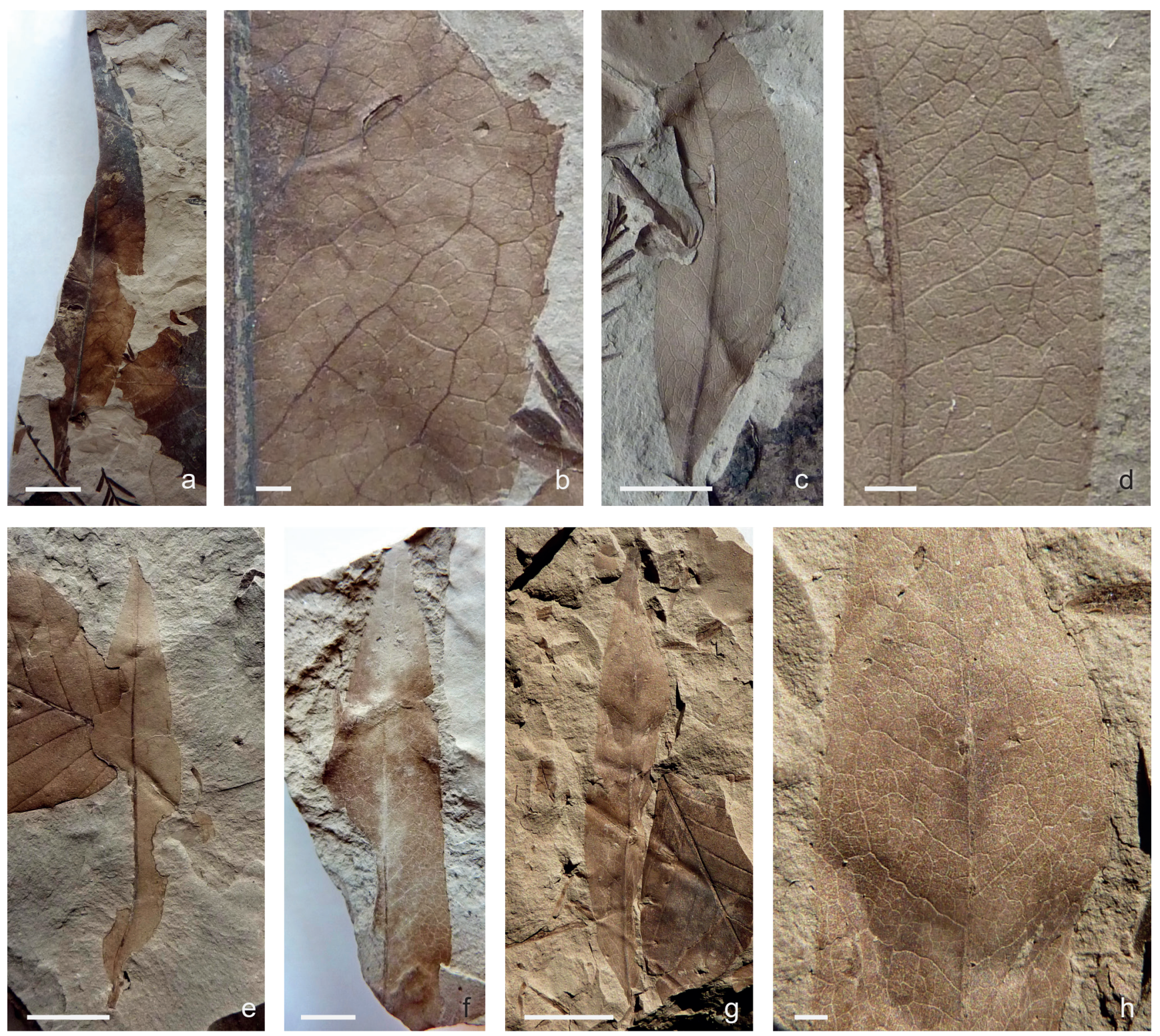

Text-fig. 6. Ternstroemites klettwitzensis sp. nov. a: Holotype, Inv.-No. 19076-2, scale bar 10 mm; b: Holotype, Inv.-No. 19076-2, detail, scale bar $1 \mathrm{~mm}$; c: Inv.-No. 18091-1, scale bar 5 mm; d: Inv.-No. 18091-1, detail, scale bar 1 mm; e: Ternstroemites klettwitzensis sp. nov., Inv.-No. 18092-1, scale bar 10 mm; f: Inv.-No. 11024-1, scale bar 5 mm; g: Inv.-No. 18093, scale bar 10 mm; h: Inv.-No. 18093, detail, scale bar $1 \mathrm{~mm}$. 

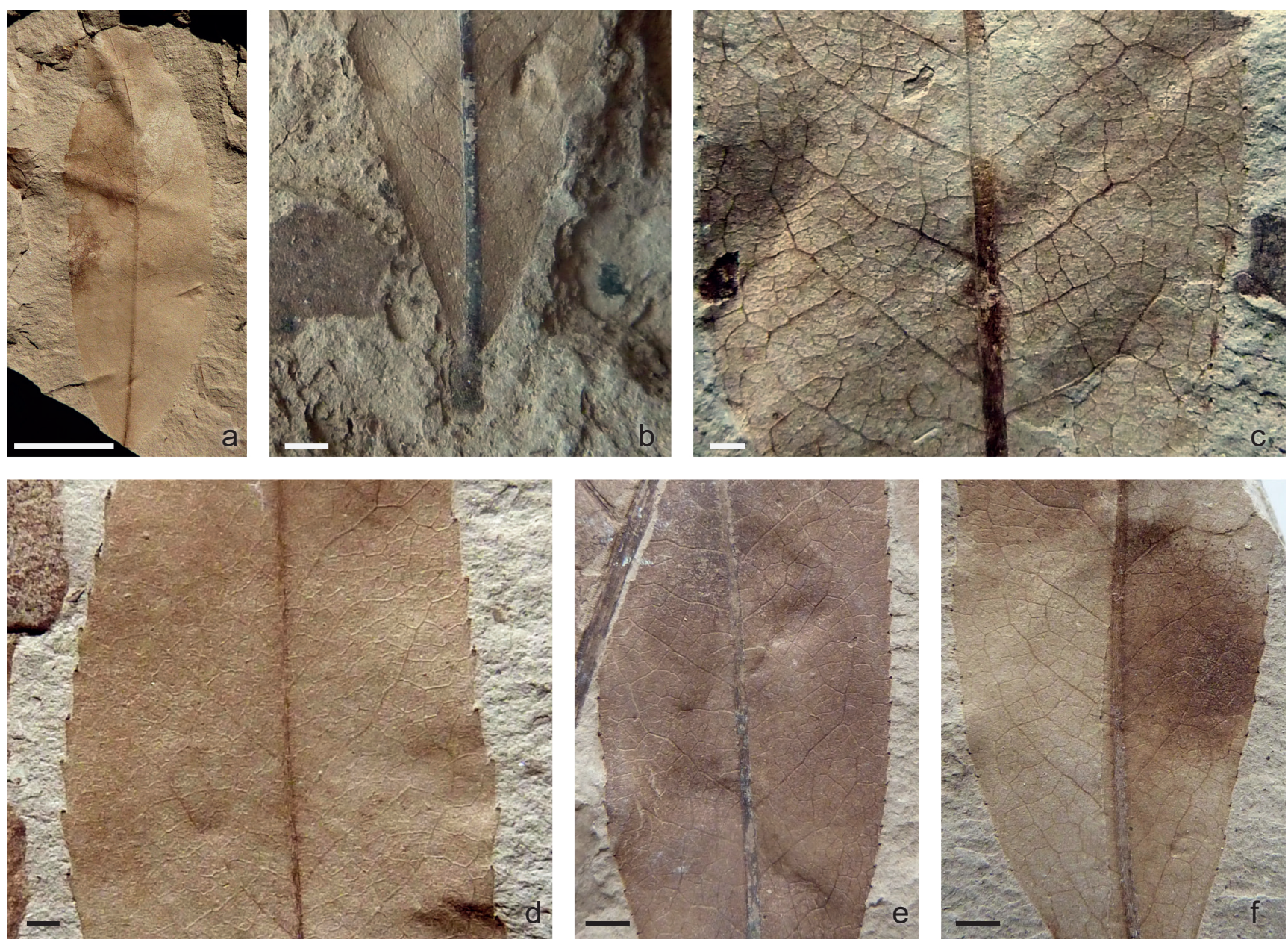

Text-fig. 7. Ternstroemites klettwitzensis sp. nov. a: Inv.-No. 18051-1, scale bar $10 \mathrm{~mm}$; b: Inv.-No. $3367-1$, scale bar $10 \mathrm{~mm}$; c: Inv.-No. 18014, scale bar 10 mm; d: Inv.-No. 18044-1, scale bar 1 mm; e: Inv.-No. 18047-1, scale bar 2 mm; f: Inv.-No. 18070-1, scale bar $2 \mathrm{~mm}$.

Because assignment to recent genera is difficult without anatomy, the new species is placed in the morphogenus Ternstroemites (type Ternstroemites eoligniticus E.W.BERRY - Berry 1916; Eocene, USA), and characterized by simple glandular teeth (after Kovar-Eder et. al. 2004).

Fossil species belonging to the morpho-genus Ternstroemites are partly anatomically documented and differ morphologically from the Wischgrund leaves.

Ternstroemites sokolovensis KVAČEK et H.WALTHER from the upper Eocene of the Staré Sedlo Formation of the Sokolov Basin (Kvaček and Walther 1984b) is long-petiolated and has an obtuse cuneate to rounded base. Leaves of Ternstroemites floersheimensis KVAČEK et H.WALTHER from the middle Oligocene of Flörsheim (Kvaček and Walther 1984b) have steeper secondary veins.

Ternstroemites bockwitzensis H.WALTHER in Mai and Walther (1991) from the upper Oligocene of the Bockwitz opencast mine near Borna differs in its broad triangular apex and broad cuneate base. Ternstroemites peregeri (UNGER) Kovar-Eder et KVAČEK in Kovar-Eder et al. (2004) from the Miocene of Parschlug in Styria, Austria has a rounded base and long petiole. Ternstroemites sp. (Worobiec and Lesiak 1998) from the Miocene of Bełchatów differs in that the arches of the secondaries go further to the margin and each gland sits in the tooth sinus.
The new species Ternstroemites klettwitzensis is established because no comparable fossil species has been found.

\section{Acknowledgement}

I thank Ass. Prof. J. Kvaček for suggesting this publication and for making it possible to publish it. I would like to thank the reviewers for their critical review and valuable comments. Special thanks also go to my husband Rolf, who always supported me with discussions, tips and the translation, as well as my daughter Iris Zachow, who made a large part of the photos.

\section{References}

Ablaev, A., Striegler, U. (1992): Kohleführende Ablagerungen des Tertiärs im Fernen Osten Rußlands im Vergleich mit der Niederlausitz. - Natur und Landschaft in der Niederlausitz, 13: 4-11.

Buckland, W. (1836): Geology and Mineralogy considered with reference to natural Theology. Vol. 1. William Pickering, London, 599 pp. [information from A. Braun in footnote on pp. 510-514] 
Fischer, O., Striegler, U. (1992): Die fossile Flora des Blättertons von Wischgrund, Teil III. - Natur und Landschaft in der Niederlausitz, 13: 12-26.

Givulescu, R. (1984): Die fossile Flora des Fundortes Chiuzbaia „H“ (Kreis Maramureș, Rumänien). - Dări de Seamă ale Şedinţelor, Institutul de Geologie şi Geofizică Bucureşti, 69(1982): 69-93.

Givulescu, R. (1990): Flora Fosila a Miocenului superior de la Chiuzbaia (Județul Maramureş) [Late Miocene fossil flora from Chiuzbaia (Județul Maramureș)]. - Editura Academiei Române, București, 237 pp. (in Romanian)

Köhler, J., Uhl, D. (2014): Die Blatt- und Karpoflora der oberoligozänen Fossillagerstätte Enspel (Westerwald, Rheinland-Pfalz, W-Deutschland). - Mainzer Naturwissenschaftliches Archiv, Beiheft 35: 1-87.

Kovar-Eder, J., Hably, L. (2006): The flora of Mataschen a unique plant assemblage from the late Miocene of Styria (Austria). - Acta Palaeobotanica, 46(2): 157-233.

Kovar-Eder, J., Jechorek, H., Kvaček, Z., Prashiv, V. (2008): The integrated plant record: An essential tool for reconstructing Neogene zonal vegetation in Europe. - Palaios, 23(2): 97-111. https://doi.org/10.2110/palo.2006.p06-039r

Kovar-Eder, J., Kvaček, Z. (2007): The integrated plant record (IPR) to reconstruct Neogene vegetation: the IPR-vegetation analyse. - Acta Palaeobotanica, 47(2): 391-418.

Kovar-Eder, J., Kvaček, Z., Ströbitzer-Hermann, M. (2004): The Miocene flora of Parschlug (Styria, Austria). - revision and synthesis. - Annalen des Naturhistorischen Museums, Wien, Ser. A, 105: 45-157.

Kovar-Eder, J., Meller, B. (2001): Plant assemblages from the hanging wall sequence of the opencast mine Oberdorf N Voitsberg, Styria (Austria, Early Miocene, Ottmangian). - Palaeontographica, Abt. B, 259: 65-112.

Kovar-Eder, J., Meller, B. (2003): The plant assemblages from the main seam parting of the western sub-basin of Oberdorf N Voitsberg, Styria, Austria (Early Miocene). Courier Forschungsinstitut Senckenberg, 241: 281-312.

Krüssmann, G. (1978): Handbuch der Laubgehölze, Band 3. - Verlag Paul Parey, Berlin, Hamburg, 496 pp.

Kunzmann, L., Kvaček, Z., Mai, D. H., Walther, H. (2009): The genus Taxodium (Cupressaceae) in the Paleogene and Neogene of Central Europe. - Review of Palaeobotany and Palynology, 153: 153-183. https://doi.org/10.1016/j.revpalbo.2008.08.003

Kvaček, Z., Walther, H. (1984a): Nachweis tertiärer Theaceen Mitteleuropas nach blatt-epidermalen Untersuchungen. I. Epidermale Merkmalskomplexe rezenter Theaceae. - Feddes Repertorium, 95(4): 209-227. https://doi.org/10.1002/fedr.4910950507

Kvaček, Z., Walther, H. (1984b): Nachweis tertiärer Theaceen Mitteleuropas nach blatt-epidermalen Untersuchungen. II. Bestimmung fossiler Theaceen-Sippen. Feddes Repertorium, 95(5-6): 331-346.

Kvaček, Z., Walther, H. (2004): Oligocene flora of Bechlejovice at Děčín from the neovolcanic area of the České středohoři Mountains, Czech Republic. - Acta Musei Nationalis Pragae, Series B - Historia Naturalis, 60: 9-60.

Mai, D. H. (1967): Die Florenzonen, der Florenwechsel und die Vorstellungen über den Klimaablauf im Jungtertiär der Deutschen Demokratischen Republik. - Abhandlungen des Zentralen Geologischen Instituts, 10: 55-81.

Mai, D. H. (1989): Die fossile Flora des Blättertons von Wischgrund und anderer gleichaltriger Fundstellen der Klettwitzer Hochfläche, Teil II. - Natur und Landschaft im Bezirk Cottbus, 11: 3-44.

Mai, D. H. (1995): Tertiäre Vegetationsgeschichte Europas. - Gustav Fischer Verlag, Jena, 691 pp.

Mai, D. H. (2000): Die mittelmiozänen und obermiozänen Floren aus der Meuroer und Raunoer Folge in der Lausitz. Teil I: Farnpflanzen, Koniferen und Monokotyledonen. - Palaeontographica, Abt. B, 256: 1-68.

Mai, D. H. (2001a): Die mittelmiozänen und obermiozänen Floren aus der Meuroer und Raunoer Folge in der Lausitz. Teil II: Dicotyledonen. - Palaeontographica, Abt. B, 257: 1-174.

Mai, D. H. (2001b): Die mittelmiozänen und obermiozänen Floren aus der Meuroer und Raunoer Folge in der Lausitz. Teil III: Fundstellen und Paläobiologie. - Palaeontographica, Abt. B, 258: 1-85.

Mai, D. H., Walther, H. (1978): Die Floren der Haselbacher Serie im Weißelster-Becken (Bezirk Leipzig, DDR). Abhandlungen des Staatlichen Museums für Mineralogie und Geologie Dresden, 28: 1-101.

Mai, D. H., Walther, H. (1991): Die oberoligozänen und untermiozänen Floren NW-Sachsens und des Bitterfelder Raumes. - Abhandlungen des Staatlichen Museums für Mineralogie und Geologie Dresden, 38: 1-230.

Médus, J., Striegler, U. (2002): Die fossile Flora des Blättertons von Wischgrund (Miozän, Niederlausitz). Teil IV: Pollen und Makroflora im Vergleich. - Natur und Landschaft in der Niederlausitz, 22: 18-37.

Menning, M. (2015): Stratigraphie. - In: Stackebrandt, W., Franke, D. (eds), Geologie von Brandenburg. Schweizerbart, Stuttgart, pp. 25-40.

Menning, M., Deutsche Stratigraphische Kommission (2012): Erläuterung zur Stratigraphischen Tabelle von Deutschland Kompakt 2012. - Zeitschrift der Deutschen Gesellschaft für Geowissenschaften, 163(4): 385-409. https://doi.org/10.1127/1860-1804/2012/0163-0385

Menzel, P. (1906): Über die Flora der Senftenberger Braunkohlen-Ablagerungen. - Abhandlungen der Preussischen Geologischen Landesanstalt, N. F., 46: 1-176.

Menzel, P., Gothan, W., Sapper, J. (1933): Neues zur Tertiärflora der Niederlausitz. - Arbeiten aus dem Institut für Paläobotanik und Petrographie der Brennsteine, 3: 1-44.

Schneider, W. (2002): Das „Lausitzer Braunkohlenmoor“ im Spreeauenpark in Cottbus. - Natur und Landschaft in der Niederlausitz, 22: 8-17.

Schweigert, G. (1992): Zur Altersstellung der Floren von Riggau und Friedersreuth (Hessenreuther Forst, Oberpfalz) mit Beschreibung von Styrax hradekense (Kvaček et Bůžek) n. comb. - Geologische Blätter für Nordost-Bayern, 42(3-4): 229-244.

Standke, G. (2015): Tertiär. - In: Stackebrandt, W., Franke, D. (eds), Geologie von Brandenburg. Schweizerbart, Stuttgart, pp. 259-333.

Standke, G., Bönisch, R., Schneider, W. (2010): Tertiär - In: Kühner, R., Bönisch, R. (eds), Die geologische Entwicklung der Lausitz. Vattenfall Europe Mining AG, Cottbus, pp. 39-94. 
Striegler, R., Striegler, U. (1984): Zugänge zur geologischen Sammlung des Bezirksmuseums Cottbus 1978 bis 1983. - Natur und Landschaft im Bezirk Cottbus, 6: 60-68.

Striegler, U. (1985): Die fossile Flora des Blättertons von Wischgrund, Teil I. - Natur und Landschaft im Bezirk Cottbus, 7: 3-35.

Striegler, U. (1990): Paleobotanical Studies in Lower Lusatia. - In: Knobloch, E., Kvaček, Z. (eds), Proceedings of the Symposium Paleofloristic and Paleoclimatic Changes in the Cretaceous and Tertiary: Prague, August 28th - September 1st, 1989. Geological Survey Publisher, Prague, pp. 233-237.

Striegler, U. (1992): Bemerkungen zu den Eichenblättern des Blättertons von Wischgrund (Miozän, Niederlausitz). - Documenta naturae, 70: 54-61.

Striegler, U. (2017): Die obermiozäne Flora des Blättertons von Wischgrund und anderer gleichaltriger Fundstellen der Klettwitzer Hochfläche (Niederlausitz, Land Brandenburg, Deutschland). - Peckiana, 12: 1-151.

Striegler, U., Striegler, R. (1981): Die paläobotanische Sammeltätigkeit des Bezirksmuseums Cottbus auf der Klettwitzer Hochfläche. - Natur und Landschaft im Bezirk Cottbus, 3: 72-84.

Striegler, U., Striegler, R. (2002): Die miozäne Flora des Blättertons von Wischgrund (bei Lauchhammer, Brandenburg) und ihre landschaftsgärtnerische Rekonstruk- tion als Niederlausitzer Tertiärwald. - Mitteilungen der Deutschen Dendrologischen Gesellschaft, 87: 125-145.

Striegler, U., Striegler, R., Zachow, I. (2004): Die Klettwitzer Hochfläche als geologisches Forschungsobjekt im Bezirksmuseum Cottbus. - Cottbuser Blätter, Sonderausgabe 2004, pp. 79-87.

Tanai, T. (1976): The Revision of the Pliocene Mogi Flora, described by Nathorst (1883) and Florin (1920). - Journal of the Faculty of Science Hokkaido University, Ser. 4, Geology and Mineralogy, 17: 277-346.

Walther, H. (1980): Der bisher älteste Nachweis der Gattung Pyracantha Roemer aus dem Tertiär Mitteleuropas. - In: Vent, E. (ed.), 100 Jahre Arboretum (1879-1979). Akademie-Verlag, Berlin, pp. 300-327.

Worobiec, G., Lesiak, M. A. (1998): Plant megafossils from the Neogene deposits of Stawek-1A (Bełchatów, Middle Poland). - Review of Palaeobotany and Palynology, 101: 179-208. https://doi.org/10.1016/S0034-6667(97)00075-4

Worobiec, G., Szynkiewicz, A. (2007): Betulaceae leaves in Miocene deposits of the Bełchatów Lignite Mine (Central Poland). - Review of Palaeobotany and Palynology, 147(1-4): 28-59. https://doi.org/10.1016/j.revpalbo.2007.06.001

Zastawniak, E. (1980): Sarmatian leafflora from the southern margin of the Holy Cross Mts. (South Poland). - Prace Muzeum Ziemi, 33: 39-107. 